\title{
The Implementation of Credit Program to Delay Cutting Down Trees
}

\author{
Satryani Kartika Ningrum Ika $^{1, *}$ and Fuad Muhamad $^{2}$ \\ ${ }^{1}$ Master program of Environmental Science, Post Graduate Studies, Diponegoro University, Semarang - Indonesia \\ 2 Departement of Biology, Faculty of Science, Mathemathics, Diponegoro University, Semarang - Indonesia
}

\begin{abstract}
Farmers have difficulty in developing community forest and their derivative products because they are constrained by funds. So, The Ministry of Environment and Forestry issued a credit program to delay cutting down trees. Loans use trees as collateral for credit. The experimental site is in Kawengen Village Ungaran East Ungaran, Semarang Regency Central Java Province $\left(7^{\circ} 1021 \mathrm{~N} 110^{\circ} 4814 \mathrm{~W}\right)$ at $216 \mathrm{~m}$ above sea level. Data is obtained from Lestari farmer grup. Lestari farmer group is a farmer organization that participates in the delayed cutting down trees credit program. The purpose of the study was to find out the implications of implementing credit program to delay cutting down trees for sustainable community forest management. The study indicated that delayed cutting loan is beneficial for farmers and forest suistainability. The result is the delay in cutting trees useful for providing longer opportunities of tree life, thus trees can be functioned ecologically and economically longer. On the other hand, if it fails to pay, there will be fragmentation of community forest land. The ecological and economic functions of trees will also be lost.
\end{abstract}

Keywords: Credit program; Community forest; trees as collateral; group of farmers.

\section{Introduction}

Farmers have difficulty finding funds to finance production activities. Farmers do not have collateral to apply for credit. So, The Ministry of Environment and Forestry issued a credit program to delay cutting down trees. Loans use trees as collateral for credit.

The results of the evaluation of the implementation of the Tree-Cutting Delay Loan program indicate that the availability of collateral is very easy to obtain, the amount of interest is quite affordable, the determination of the maximum loan size is very appropriate, the activities financed are right on target and the mechanism of repayment is considered easy [1].

The development of credit schemes to fund community-based forest development in Indonesia has been done for a long time. In 1988-1998, there was a credit program for Watershed Conservation, then in 1997-2000, Community Forest Business Credit was provided. Since 2008, a credit scheme has been developed for the community plantation forest revolving fund to accelerate the development of the community forest. In its journey, it turns out that Credit Program for Watershed Conservation and Community Forest Business Credit has caused many problems at this time. The problems are the number of arrears, plants as investment returns not found, inaccurate data collection, and so forth. While a credit program for the community plantation forest revolving fund performance has not been known. Until October 2010, the available funds have not been distributed at all [2]

Giving credit to the farming community can be a lever for the economy of farmers to increase. But on the other hand, prudence in giving credit must remain the most important thing, because the loan guarantees are trees in the community forest. Based on the regulation of the minister of forestry of The Republic of Indonesia, community forest is forest outside the state forest area and grows on land that burdened with land rights.

Community forests have the opportunity to obtain funding in the form of incentives because community forests not only have economic and social functions but also provide benefits to the environment (public). Now, opportunities for community forest credit can be obtained through government programs, because currently, the government will expand financing services for community forest businesses. The community forest business with a certain pattern at the $12 \%$ interest rate is financially feasible making it possible to obtain commercial funding sources, but banks still do not see community forest businesses with tree domination as bankable businesses. So, the credit for community forests requires government intervention. The government can support capital in the form of loans/subsidies or as a guarantor of community forest business loans [3].

The purpose of the study was to find out the implications of implementing the credit program to delay

\footnotetext{
* Corresponding author: ikahutan@gmail.com
} 
cutting down trees for sustainable community forest management.

\section{Material and methods}

\subsection{Study Area}

The experimental site is in Kawengen Village East Ungaran District Semarang Regency Central Java Province $\left(7^{\circ} 1021 \mathrm{~N} 110^{\circ} 4814 \mathrm{~W}\right)$ at $216 \mathrm{~m}$ above sea level. The area of kawengen village is 752.81 hectares.

The three major crops cultivated at the site are Sengon (Albazia chinensis), Teak (Tectona grandis) and Mahogany (Swietenia macrophylla King). The mean annual precipitation is $3316 \mathrm{~mm}$ and mainly comes between September and March.

The population of Kawengen village is 7,059 people. The number of people who work as farmers is 887 people. Therefore, only around $10 \%$ are community forest farmers. While as many as $90 \%$ are farmers in cultivating rice fields.

The area of kawengen village is 752.81 hectares. The area is divided into 445.03 hectares of agricultural land and 307.78 hectares of non-agricultural land area. From the area of agricultural land, it is divided into 112.60 hectares of rice fields and 332.43 hectares of land rather than rice fields. The area of community forest land is 95,52 hectares.

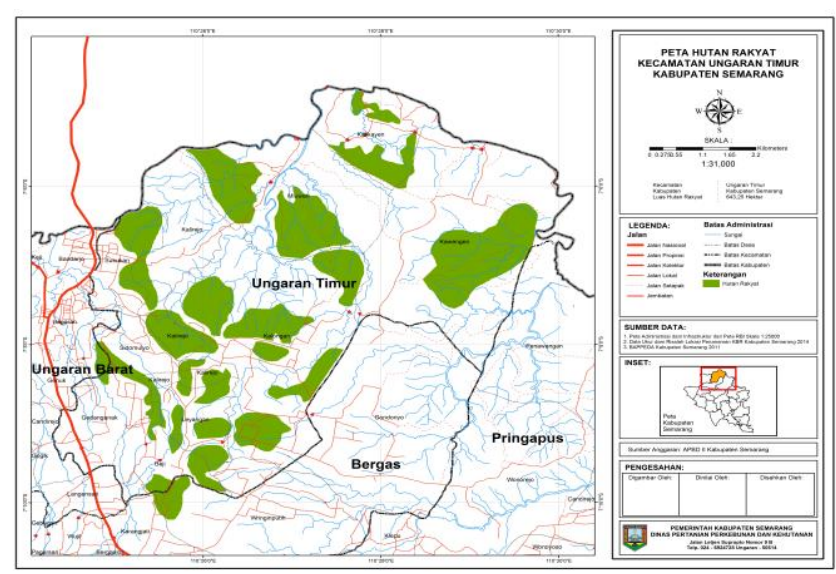

Fig. 1. Map of community forest in Ungaran Timur

\subsection{Sampling}

Data is obtained from Lestari farmer grup. Lestari farmer group is a farmer organization that participates in the delayed cutting down trees credit program.

\subsection{Methods}

The study was conducted in September 2018 - January 2019, which included the preparation of research design, observation, deep interview, data processing, and analysis. The methods used are observation, interview, and literature study.
The type of data used in the study is primary data and secondary data. Primary data was collected through indepth interviews with key informants who were deliberately selected (purposive sampling) [4]. Secondary data is collected by studying various writings, drawings or monumental works related to the research topic [5].

In order to obtain an overview of the implementation of the loan program that delayed logging, interviews were conducted with all program participants. Interviews were also conducted with the head of the village government, officials from the Environment and Forestry Ministries, and also officials from Environment and Forestry Services of the Central Java Province.

\section{Results}

The number of farmers participating in the credit program is 33 people. The study respondents consisted of $12 \%$ of women and $88 \%$ of men. The survey results indicate the borrower's age varies, there are $18 \%$ of respondents aged $>60$ years, $18 \%$ of respondents aged $50-59$ years, $49 \%$ of respondents aged $40-49$ years, and $15 \%$ aged $30-39$ years.

The area of community forest included in the credit program is 13.1737 hectares, with the number of trees is 4.998 trees. There are 23 borrowers $(70 \%)$ with an area of $<0.4,8$ people $(24 \%)$ within the area of $0.4-0.8$ hectares, and 2 people $(6 \%)$ within the area of $>0.8$ hectares.

Table 1. Loan data in Lestari farmer group.

\begin{tabular}{|c|c|}
\hline Description & Amount \\
\hline Debtor & 33 people \\
\hline Collateral Tree & 4,998 trees \\
\hline Land area & 13.1737 hectares \\
\hline Debt & Rp $1,738,840,000,-$. \\
\hline
\end{tabular}

The number of trees covered by collateral is 4,998 trees. The tree that is used as collateral has around the stem of at least $40 \mathrm{~cm}$. The most pledged tree species are teak. The customer chooses teak (Tectona grandis L. f.) to be used as collateral because of its high selling value. The debtor expects that the money obtained from credit will delay cutting down trees.

Teak trees are harvested when plants have reached economic limits. In general, the main benchmark is the stem diameter of about 40 centimeters, if measured at 1 meter above ground level. Teak is strong class conditions wood and high durability wood but easy to work on. Teak wood is widely used for building materials, home furnishings, and craft items. Products made from teak wood usually have a high selling price. 
Teak is one of the most sought after wood species because it has a unique and elegant style, strong, durable, stable, and easy to work on [6].

Numbering and measurement of trees submitted by collateral are carried out by the debtor. Interview result showed that the numbering procedure and measurement of the circumference of trees used as collateral was difficult for respondents. The debtor complains about numbering and difficult circumference measurements.

The next step is re-measurement by officers from the Ministry of Environment and Forestry. The officer verified the numbering and measurement of the tree.

The procedures for applications are classified as complicated. Socialization is still considered to be lacking. The timing of loan disbursement is not timely and long. The procedures for channeling loan funds are not appropriate. Guidance and monitoring are considered to be lacking [1].

Table 2. Amount and circumference of trees used as collateral.

\begin{tabular}{|c|c|c|}
\hline Circumference & Teak & Mahogany \\
\hline $30-46 \mathrm{~cm}$ & 2,486 trees & 6 trees \\
\hline $47-64 \mathrm{~cm}$ & 1,483 trees & 10 trees \\
\hline $65-74 \mathrm{~cm}$ & 425 trees & 3 trees \\
\hline $75-84 \mathrm{~cm}$ & 239 trees & 16 trees \\
\hline $85-90 \mathrm{~cm}$ & 123 trees & 2 trees \\
\hline $90 \mathrm{~cm} \mathrm{up}$ & 203 trees & 2 trees \\
\hline
\end{tabular}

The heavy duty of the officer is to keep the trees used as collateral alive until the debt maturity. So far, officers only rely on reports from debtors to find out the existence of the collateral tree. In the future, barcode technology is needed to identify the existence of trees. So that it is easier for tree supervision to become collateral for the debt.

The area of community forest in Kawengen Village is 95,52 hectares. The area of community forest included in the credit program is $13,79 \%$ of the total community forest area in Kawengen Village.

If the credit is not paid, the community forest area will be fragmented. Fragmentation causes a reduction in the function of the forest as a habitat for various species plants and wildlife. This is quite worrying, not only because of the increasingly widespread consequences of human life, namely the increasing frequency and intensity of floods and droughts but also threatens the preservation of biodiversity. Biodiversity is also a buffer for human life [7]. Conversion, degradation, and fragmentation are threats to the integrity forest ecosystem in the world [8].

If community forest fragmentation occurs, then the function of environmental services will be lost. Environmental service activities that can be carried out in the utilization of environmental services are the utilization of water flow services, water utilization, natural tourism, biodiversity protection, and carbon sequestration and/or storage.

The other research showed fragmented landscapes in the Amazon experience diverse changes in forest dynamics, structure, composition and microclimate and are highly vulnerable to droughts and fires-alterations that negatively affect a wide variety of animal species. In human-dominated lands, intensive hunting may interact synergistically with fragmentation to further threaten wildlife populations [9].

The existence of ecosystem services or forest environmental services is strongly influenced by the parties' perceptions of the value of these services, but the main obstacle is the value of forest ecosystem services that are difficult to cash. It is different from the tangible benefits of forests such as timber, rattan, fish, and game animals that can be sold and consumed. So little environmental services are evident because they are external. But if the parties also take into account other values of the existence of forests such as forest carbon values, then the value of the tree as a habitat for other animals or plants, then logging will eliminate the invisible values [10].

If fragmented land is not planted immediately, it will cause critical land. Critical land can also be defined as land that is not suitable between the ability of the land and its use. That because of physical, chemical and biological damage that endangers the hydrological, socio-economic, agricultural production or settlement functions. This can lead to erosion disasters and landslides in the upstream area as well as sedimentation and flooding in the downstream area [11]. Critical land can cause natural disasters, such as floods, erosion, and drought. Another impact of the presence of critical land is a decrease in soil fertility.

The value of credit loans postpones cutting down trees is Rp. 1.738.840.000,-. A total of 21 debtors used loan funds for livestock businesses. The rest is for businesses, such as shops and welding workshops. One debtor uses loan money for the cost of medical education. The use of funds for education at that time is permitted, at the discretion of the officer, to see the character of the debtor who is responsible. The officer also considered the debtor's work as the village head.

The feasibility of this type of business must be considered carefully. Based on the results of interviews with the government, business assistance is needed for the debtors. Mentoring is needed so that the business developed with debt funds can run well. So that from the results of business profits, the debtor can pay the debt installments.

One of the drawbacks of tree-delaying loans is that there is no verification of loan history from debtors. Debtors who previously have arrears on loans from other credit can still get loans postponing the felling of trees.

In the future, a track record of credit arrears from prospective debtors is required. Credit is given to people who have never had a debt problem. In addition, input from local community leaders regarding the character of the prospective debtor is needed. So that it is known, 
prospective borrowers have the ability and willingness to pay debts.

On the other hand, the use of national banks with credit experience for small businesses provides more assurance of smooth operations. Recently, the idea emerged to form a "green bank" as a financial institution in the security sector, especially in the development forest considering these activities have special characteristics. In addition, the role of banks can be increased to implementers as other lending activities so that they have greater responsibility for credit operations and returns [12].

The delay in cutting trees is useful for providing longer opportunities for tree life, thus trees can function ecologically longer. Trees become ripe cut so that they provide more optimal ecological and economic functions.

These trees have delivered some benefits, including aesthetic values and the amelioration of climatic extremes. However, it was considered that the benefits might extend to pollution mitigation and the sequestration of carbon [13].

Trees provide many ecological benefits for ecosystems, among others: maintaining the surrounding microclimate, maintaining the water system, becoming a habitat for fauna and microorganisms and providing additional functions for other plants under the canopy as shade. In some conditions, the presence of trees can be a protection against wind exposure as in agroforestry systems in coastal areas. On the other hand, the community planted trees to meet the medium-term economic needs of commodities in the form of fruits and long-term production of woodworking raw materials produced [14].

Environmental services produced by community forest businesses are a form of positive externalities that can be categorized as public goods. For example, carbon sequestration by community forests can improve air quality so that it benefits all community members [15].

Economically, loans provide benefits to farmers. The loan was used for working capital. Farmers still have trees, while the money earned can be used for productive activities. The money from business activities can be used to pay installments.

A credit scheme aimed at small holders of privateforests or forest farming is a major effort to carry out greening (afforestation) to produce timber and or other forest products and to conserve land by involving community participation. Results of the study reveal several findings: (1) Credit schemes should be flexibly adapted to region socio-economic conditions; (ii) Farmers' partner should be selectively chosen to ensure credit repayment; (iii) Bank role in credit channeling should be adapted to the objective of the underlying program, and (iv) In the funding aspect, blend of funds of reforestation fund, national banks, and low rate oversea funding need to be sought [12].

In the future, community forests need to be empowered better. Community forests need to be developed as an agribusiness system or business agroforest to expand revenues from banks and other financial institutions. In this system business management units and economies of scale, commodities, and linkages with markets (industries) need to be clarified [12].

\section{Conclusion}

In the present study indicated that delayed cutting loan is beneficial for farmers and forest sustainability. If the credit is not paid, the community forest area will be fragmented. Fragmentation causes a reduction in the function of the forest as a habitat for various species plants and wildlife. If community forest fragmentation occurs, then the function of environmental services will be lost.

If a debt is not paid, the tree as collateral is cutting down. So that the ecological and economic functions of trees will also be lost.

At the time of the study, farmers had not made credit installments. So the smoothness of installment payments is unknown. In the future, research is needed on the loan repayment rate. So that it is known the effectiveness of using loan money. This study opens the opportunity to further evaluate the credit program to delay cutting down trees.

\section{References}

1. T.W. Almadina, Evaluasi Pinjaman Tunda Tebang Dana bergulir di Kabupaten Pacitan, Faculty of Forestry - UGM Yogyakarta (2016)

2. B. Nugroho, Analisis Perbandingan Beberapa Skema Pinjaman untuk Pembangunan Hutan Tanaman Berbasis Masyarakat di Indonesia, JMHT XVII, 79-88 (2011)

3. E. Fauziyah, Sainudin, Peluang Pendanaan Bagi Pengusahaan Hutan Rakyat, Balai Penelitian Teknologi Agroforestri Ciamis (2012)

4. A. Prastowo, Metode Penelitian Kualitatif, Ar-Ruzz Media Yogyakarta (2011)

5. Sugiyono, Metode Penelitian Kombinasi - Mixed Methods, Alfabeta Bandung (2011)

6. Tagfira, S. Umar, A.S. Alam, Pendapatan Petani Pengusahaan Kayu Jati (Tectona grandis) Di Desa Povelua Kecamatan Banawa tengah Kabupaten Donggala, JWR 6(3), 1-6 (2018)

7. H. Gunawan, L.B. Prasetyo, A. Mardiastuti, A.P. Kartono, Fragmentation of Dryland Natural Forest in Central Java Province), JPHKA VII, 75-91 (2009)

8. S. Rifanjani, Fragmentasi Hutan dan Pengaruhnya terhadap Penggunaan Ruang Habitat Orang Utan di Taman Nasional Gunung Palung - Disertasi, Forestry Postgraduate Program UGM-Yogyakarta (2015)

9. W.F Laurance, H.L Vasconcelos, T.E. Lovejoy, Forest Loss and Fragmentation in the Amazon : Implications for Wildlife Conservation, Oryx 34(1), 39 - 45 (2000) 
10. M.Z. Mutaqqin, I. Samsoedin, Subarudi, Nurtjahjawilasa, F.A.U. Hamdani, Pemanfaatan Jasa Lingkungan Di Hutan Desa Buntoi Kecamatan Kahayan Hilir, Kabupaten Pulang Pisau, Provinsi Kalimantan Tengah, JAKH 14, 1-16 (2017)

11. M. Rosyada, Y. Prasetyo, Hani'ah, Penentuan Tingkat Lahan Kritis Menggunakan Metode Pembobotan dan Algoritma NDVI (Studi Kasus Sub Das Garang Hulu), JGU 4(1), 85 - 94 (2015)

12. H.D. Prabowo, Analisa Kebijakan Skema Kredit dan Pembiayaan Usaha tani Hutan, JAKH 2(2), 89-100 (2005)

13. C.L. Brack, Pollution Mitigation and Carbon Sequestration by An Urban Forest, EP 116(1), S195-S200 (2002)

14. A. Winara, A. Widayanto, Jasa Lingkungan Agroforestri - Keanekaragaman Jenis Pohon pada Sistem Agroforestri di DAS Balangtieng, PT Penerbit IPB Press, Bogor (2018)

15. E. Irawan, Nilai Ekonomi Hutan Rakyat untuk Penyerapan Emisi Karbon, JPSEK 8(1), 54 - 70 (2011) 